\title{
Dialogue Amidst Multiformity: A Habermasian Breakthrough in the Development of Anglican Eucharistic Liturgies
}

\author{
Brian Douglas and Terence Lovat ${ }^{1}$ \\ brian.douglas@mac.com, Terry.Lovat@newcastle.edu.au
}

\begin{abstract}
This article argues that a breakthrough is possible in the development of Anglican eucharistic liturgies. A dialogue approach holds out the promise of distancing the process of liturgical development from party spirit and particular interest, and focusing it instead on the self-reflection and intersubjectivity of communicative action, while also recognizing the multiformity of philosophical assumptions underlying the Anglican eucharistic tradition. Such a process has potential to emancipate the Anglican eucharistic tradition from conflict and centre attention on a more critical selfreflection on the discourse of the tradition. Eucharistic liturgies in use in Australia are considered in terms of their underlying philosophical assumptions, and recommendations are made for the use of a dialogue approach based on Habermas's theory of communicative action.
\end{abstract}

KEYWORDS: Anglican, communicative action, Eucharist, Habermas, liturgy

\section{The Multiformity of Anglican Eucharistic Theology}

Lovat and Douglas ${ }^{2}$ argue that Anglican eucharistic theology is multiform, that is, it is characterized by a multiplicity of views with many voices actually competing with one another. This multiformity

1. Brian Douglas, Rector St Paul's Anglican Church, Manuka, Australia; Lecturer in Theology at St Mark's National Theological Centre, Canberra and Conjoint Lecturer, University of Newcastle, Australia. Terence Lovat, Pro ViceChancellor (Education and Arts) University of Newcastle, Australia.

2. T. Lovat and B. Douglas, 'Dialogue Amidst Difference in Anglican Eucharistic Theology: A Habermasian Breakthrough', Australian EJournal of Theology, 
revolves around the competing voices of various church parties and interests, each of which seeks to propagate its 'truth' in a search for theological and doctrinal purity (often Anglican Catholic or Anglican Evangelical), or even as political power within the Anglican Communion (Kaye ${ }^{3}$ and Williams ${ }^{4}$ ). This desire for 'purity' and power often inhibits dialogue within the tradition as a whole, since the focus is too firmly centred on having 'the' truth rather than any critical reflection on truth within the tradition as a whole.

\section{Critical Theory: A Breakthrough for Anglican Eucharistic Theology}

Lovat and Douglas ${ }^{5}$ argue that where dialogue exists amidst the difference or multiformity of the Anglican eucharistic tradition, then there is the possibility of a breakthrough for the tradition, such that a more critical analysis is possible than the mere prosecution of party positions and interests. This article argues more specifically that this breakthrough is also possible in any consideration of Anglican eucharistic liturgies.

In putting the case for dialogue and communicative action in relation to Anglican eucharistic theology, Lovat and Douglas ${ }^{6}$ take note of the work of the contemporary critical theorist Jurgen Habermas. ${ }^{7}$ Habermas draws attention to various 'ways of knowing', called 'empiricalanalytic', 'historical-hermeneutic' and 'self-reflective' in an attempt to explore the question: 'How is reliable knowledge possible?'. ${ }^{8}$ In the

(F'note continued)

9 (March 2007), online at http://dlibrary.acu.edu.au/research/theology/ejournal/ aejt_9/lovat.htm. Accessed 6 January, 2008.

3. Bruce Kaye, Reinventing Anglicanism: A Vision of confidence, community and engagement in Anglican Christianity (Adelaide: Open Book, 2003).

4. Rowan Williams, 'The challenge and hope of being an Anglican today: A reflection for the bishops, clergy and faithful of the Anglican Communion', Anglican Communion News Service, ACNS 4161, Lambeth, 27 June 2006, online at http://anglicancommunion.org/acns/articles/41/50/acns4161.cfm. Accessed 6 January, 2008.

5. Lovat and Douglas, 'Dialogue'.

6. Lovat and Douglas, 'Dialogue'.

7. Jurgen Habermas, Knowledge and Human Interests (trans. J.J. Shapiro) (Boston: Beacon Press, 1971), Theory and Practice (trans. T. McCarthy) (Boston: Beacon Press, 1973), The Theory of Communicative Action. Volume 1. Reason and the Rationalization of Society (trans. T. McCarthy) (Boston: Beacon Press, 1984) and The Theory of Communicative Action. Volume 2. Lifeworld and System: A Critique of Functionalist Reason (trans. T. McCarthy) (Boston: Beacon Press, 1989).

8. Habermas, Knowledge and Human Interests, p. 3. 
empirical-analytic way of knowing, the goal is to amass essential facts and figures so as to manage one's world, whereas in the historicalhermeneutic the goal of knowing is to interpret information in order to understand one's world. This historical-hermeneutic way of knowing is often the basis of the search for knowledge by those who adopt particular party interests, and who are intent on pursuing a particular truth in order to perpetuate or develop their interests within the confines of what Habermas calls, their own lifeworld. At best, this functions as a form of enculturation or assimilation into a lifeworld and, at worst, as indoctrination of others into a party position. Habermas's third way or self-reflective way of knowing however, is concerned with knowing in a critical way and examines the reliability of one's knowledge in an attempt to move past partisan positions, often accepted uncritically by particular parties or interests. The Habermasian scheme of self-reflection holds out the hope of being emancipated from the constraints of party interest. Self-reflection, for Habermas, aims at attaining knowledge in a critical manner, not merely as the lifeworld of individuals or groups but as a dynamic system of interactions between speakers and hearers, a kind of subjectto-subject encounter. In this, the focus is on what Habermas refers to as 'dialogue', an intersubjectivity of communicative action where interactions between speakers comprise 'discourse'. Discourse here stands in contrast to the kind of intersubjectivity that sees particular party interests engaged in subject-to-object encounters aimed at their own version of reliable knowledge. ${ }^{9}$

Lovat and Douglas ${ }^{10}$ suggest that a process of communicative action holds out the promise of engaging the discourse of the Anglican eucharistic tradition in a more genuine dialogue of self-reflection than the prosecution of particular party positions and interests. This implies a movement from what McCarthy calls 'hermeneutic idealism' ${ }^{11}$ or a focus on the particular interests of party positions (subject-object) to a position of reflection on the tradition as whole, not only as a more critical and self-reflective way of knowing, but as a way of lessening tension, and promoting intersubjectivity and understanding within the Anglican Communion (subject-subject). Lovat and Douglas conclude with a warning: 'Habermas's work suggests that if ownership of particular hermeneutic interests is the focus of Anglicans, its

9. Habermas, Theory. Volume 1, p. 106.

10. Lovat and Douglas, 'Dialogue'.

11. Thomas McCarthy, 'Translator's Introduction', in J. Habermas, Theory. Volume 1, p. xxvi. 
eucharistic tradition and its theological education generally, then the society that is Anglicanism will continue to deform and atrophy'. ${ }^{12}$ Communicative action based on dialogue and self-reflection, is therefore recommended as the way forward for Anglican eucharistic theology and for theological education generally in the Anglican tradition, since it takes seriously the multiformity of the tradition and seeks to work with this multiformity of the tradition, rather than with particular party interests. This has the advantage of encouraging open dialogue, critical interest, shared meaning and an ideal communicative community, rather than the maintenance of closed communities and knowledge, acrimonious debate and the presumption of privileged knowledge and position within the totality of the Anglican tradition.

\section{A Further Breakthrough: Philosophical Assumptions}

Philosophical assumptions underlying eucharistic theology are also part of the multiformity of the Anglican eucharistic tradition and worthy of exploration as part of the continuing dialogue that is communicative action. The consideration of philosophical assumptions underlying Anglican eucharistic theology is a further breakthrough for this tradition, since such consideration seeks to move past the hermeneutic idealism so common in church parties and, in so doing, provides access to more reflective and critical levels of knowledge concerning the tradition. This article argues that such a breakthrough is useful in an examination of the philosophical assumptions underlying eucharistic liturgies, and that benefits flow to the tradition as a whole, especially its process of liturgical development, if this is undertaken in the context of communicative action rather than adversarial debate.

\section{Philosophical Assumptions of the Anglican Eucharistic Tradition}

Douglas ${ }^{13}$ has noted that some within the Anglican tradition express a eucharistic theology based on realist philosophical assumptions, that is, where the signs or particulars of the Eucharist (the bread and wine and their offering) convey the signified grace of Christ to the

12. Lovat and Douglas, 'Dialogue', p. 9.

13. Brian Douglas, Ways of Knowing in the Anglican Eucharistic Tradition: Ramifications for Theological Education (A thesis submitted in fulfilment of the requirements for the degree of Doctor of Philosophy at the University of Newcastle, Australia, 2006), online at http://www.newcastle.edu.au/service/library/ adt/public/adt-NNCU20070511.140205. Accessed 6 January, 2008. 
communicant in what is called the 'real presence of Christ in the Eucharist' or the 'eucharistic sacrifice', such that the signs or particulars convey the signified grace (see also the realist assumptions of Macquarrie $^{14}$ and Williams ${ }^{15}$ ). Douglas ${ }^{16}$ has also noted that other Anglicans base their eucharistic theology on nominalist assumptions, that is, arguing that there is no real link between the signs of the Eucharist and the signified grace, that the signs and the signified are self-enclosed entities without any real linking of signs to any universal concept beyond the particular signs themselves. For those adopting a nominalist analysis, the argument is put that grace is bestowed on the basis of faith alone and cannot be conveyed by signs such as bread and wine or their offering in the Eucharist (see the nominalist assumptions of Doyle ${ }^{17}$ and Zahl ${ }^{18}$ ). For these Anglicans, grace is limited to the events of the cross and its once-and-for-all application, and this cannot be contextualized or objectified in any real way in the present through signs or particulars in the Eucharist but by faith alone.

Conceptualizing Anglican eucharistic theology by means of the philosophical assumptions of realism and nominalism is an emerging venture for Anglican theology. The work of Douglas ${ }^{19}$ has pointed to how these philosophical assumptions can be useful in reflecting on the nature of Anglican eucharistic theology and theological education beyond the confines of party positions and interests. Douglas ${ }^{20}$ observes that the use of these philosophical assumptions depends heavily on the work of contemporary philosophers, principally the work of the Australian philosopher David Armstrong, ${ }^{21}$ although

14. John Macquarrie, A Guide to the Sacraments (London: SCM Press, 1997).

15. Rowan Williams, On Christian Theology (Oxford: Blackwell, 2000).

16. Douglas, Ways of Knowing and Anglican Eucharistic Theology.

17. Robert Doyle, 'Word and sacrament in catholic and evangelical theology', in I. Head (ed.), Who may celebrate? Boundaries of Anglican order (Sydney: The Standing Committee of General Synod of the Anglican Church of Australia, 1996). A Second Publication of the Doctrine Commission of the General Synod on the Identity of the Eucharistic President or Administrant of Holy Communion..

18. Paul Zahl, A Short Systematic Theology (Grand Rapids, Michigan: Eerdmans, 2000).

19. Douglas, Ways of Knowing.

20. Douglas, Ways of Knowing.

21. David Armstrong, Universals. An Opinionated Introduction (Boulder, Colorado: Westview, 1989), Nominalism and Realism. Universals and Scientific Realism, Volume 1 (Cambridge: Cambridge University Press, 1995), A World of States of Affairs (Cambridge: Cambridge University Press, 1997) and Truth and Truthmakers (Cambridge: Cambridge University Press, 1997). 
Armstrong himself never applied his work to any study of eucharistic theology. One of the guiding principles of the research of Douglas ${ }^{22}$ was an attempt to move past the hermeneutic idealism of party interest in Anglicanism, and to engage with more critical methods of reflection on the tradition as a whole using the insights of contemporary philosophers such as Armstrong. Using a methodology of phenomenology, Douglas ${ }^{23}$ examined the philosophical assumptions of a large collection of Anglican writers on eucharistic theology from the Reformation to the present (this material is available at Douglas ${ }^{24}$ ). The purpose was to extract the essences of Anglican eucharistic theology and the conclusion reached was that the philosophical distinction between realism and nominalism was a distinguishing feature of the multiformity of Anglican eucharistic theology. The question arises therefore: Can this distinction between philosophical assumptions be a further breakthrough in promoting dialogue and communicative action in the Anglican eucharistic tradition?

The remainder of this article, therefore, seeks to reflect on how this distinction between the realist and nominalist philosophical assumptions of Anglican eucharistic theology is found within the eucharistic liturgies of one part of the Anglican Communion, that is, the Anglican Church of Australia. Furthermore, the article will suggest how this distinction can be useful in developing dialogue in the liturgical work of the Anglican tradition based on communicative action.

\section{Anglican Eucharistic Liturgies: Multiformity of Philosophical Assumptions}

Anglican eucharistic liturgies are most often found within the various prayer books of the Anglican Communion. Hefling ${ }^{25}$ points out that each of the Provinces of the worldwide Anglican Communion develops and uses its own prayer book and in so doing defines particular interests of eucharistic theology. Whilst there are important similarities in many of the eucharistic liturgies of the prayer books of

22. Douglas, Ways of Knowing.

23. Douglas, Ways of Knowing.

24. Brian Douglas, Anglican Eucharistic Theology (A website of case studies developed as part of the research for the degree of Doctor of Philosophy, University of Newcastle, 2006), online at http://web.mac.com/brian.douglas. Accessed 6 January, 2008.

25. Charles Hefling, 'Introduction: Anglicans and Common Prayer', in C. Hefling and C. Shattuck (eds.), The Oxford Guide to The Book of Common Prayer: A Worldwide Survey (Oxford: Oxford University Press, 2006), p. 1. 
the Anglican Communion, Dowling ${ }^{26}$ observes that there are also significant differences in style and eucharistic theology. Dowling ${ }^{27}$ also argues that the eucharistic theology of liturgies is determined by a variety of means, including the way the text of the liturgy is enacted and the use of symbols. While Anglican theologians have defined eucharistic theology in systematic ways (e.g., Macquarrie ${ }^{28}$ and $\mathrm{Zahl}^{29}$ ) Dowling ${ }^{30}$ argues that Anglicanism is more likely to express its eucharistic theology through its liturgies and the way these liturgies are experienced. This suggests that an examination of eucharistic liturgies is an important area of reflection in the Anglican tradition, however, we add the further suggestion that an analysis of the philosophical assumptions underlying Anglican eucharistic liturgies and their theology is also important. We put the case that unless these philosophical assumptions are adequately explored, the hope of critical self-reflection within the Anglican tradition will be limited. Conversely, the analysis of philosophical assumptions holds out the hope of further emancipating the Anglican eucharistic tradition from the strangle-hold of party position and interest. Whilst we acknowledge that the exploration of these philosophical categories has a narrow focus in terms of eucharistic theology, wider exploration is beyond the scope of this article.

Anglican Eucharistic Liturgies in the Anglican Church of Australia: A Study in the Hermeneutic Idealism of A Prayer Book for Australia (1995)

Whilst the following discussion focuses on the Australian Anglican scene and specifically the current prayer book (A Prayer Book for Australia, 1995), there are, nonetheless, implications for the wider Anglican Communion. The process of liturgical revision in the Anglican Communion often involves people with very different understandings of the Eucharist. The hermeneutic idealism present in the revision process has the potential to make agreement difficult, especially if particular interests insist on prosecuting their views to the exclusion of others. Readers in the wider Anglican Communion may

26. Ron Dowling, 'The Eucharist', in C. Hefling and C. Shattuck (eds.), The Oxford Guide to The Book of Common Prayer: A Worldwide Survey (Oxford: Oxford University Press, 2006), p. 467.

27. Dowling, 'The Eucharist', p. 467.

28. Macquarrie, Guide.

29. Zahl, Systematic.

30. Dowling, 'The Eucharist', p. 467. 
well be able to apply this analysis to the development of Eucharistic liturgies, in their particular situation, in the same way that it has been applied to the Anglican Church of Australia and its eucharistic liturgies.

The current prayer book of the Anglican Church of Australia, A Prayer Book for Australia (1995) or APBA (1995) ${ }^{31}$ has three eucharistic liturgies - First, Second and Third Orders. The First Order is a modern language translation of the 1662 Book of Common Prayer $(B C P)$ and because of space restrictions will not be considered here.

\section{The Second Order Eucharist of APBA (1995)}

The Second Order Eucharist has five thanksgiving prayers, ${ }^{32}$ which will be analysed in terms of the philosophical assumptions of realism and nominalism. Thanksgiving 1 includes an epiclesis or invocation of the Holy Spirit over the bread and wine expressed in a realist form. It reads:

Merciful God, we thank you for these gifts of your creation, this bread and wine, and we pray that by your Word and Holy Spirit, we who eat and drink them, may be partakers of Christ's body and blood. ${ }^{33}$

The bread and wine are clearly associated with the body and blood of Christ through the power of the Word and Holy Spirit, although the wording of 'partakers of Christ's body and blood' is preferred to the more developed realist forms of the epiclesis, found in some other Anglican eucharistic liturgies (e.g., The Episcopal Church's 1979 BCP where the form of words asks that the bread and wine may 'be unto us' the Body and Blood of Christ, ${ }^{34}$ or the Southern African Church's 1989 An Anglican Prayer Book where the form of words are 'so that they may become for us the body and blood of our Lord, Jesus Christ' ${ }^{35}$ ). Use of 'partakers' lessens the realist connection of bread/wine and body/blood in APBA, since it focuses more on the act of reception or partaking than on the making or changing of the elements into the body and blood of Christ.

The anamnesis or memorial of the mighty acts of Christ in death, resurrection, ascension and glorification in Thanksgiving 1 also presents

31. A Prayer Book for Australia (APBA) (Sydney: Broughton Book, 1995).

32. APBA, pp. $128-140$.

33. APBA, p. 128.

34. Book of Common Prayer (The Episcopal Church, New York: The Church Hymnal Corporation, 1979), p. 342.

35. An Anglican Prayer Book (The Anglican Church of Southern Africa, London: Collins, 1989), p. 123. 
a realist understanding, linking the bread and wine with the celebration of the mighty acts of Christ, whilst at the same time referring to the one, perfect and sufficient sacrifice and thus, preventing any assumption of a fleshy re-offering of Christ in the Eucharist. The anamnesis reads:

Therefore we do as our Saviour has commanded: proclaiming his offering of himself made once for all upon the cross, his mighty resurrection and glorious ascension, and looking for his coming again, we celebrate, with this bread and this cup, his one perfect and sufficient sacrifice for the sins of the whole world. ${ }^{36}$

The anamnesis stops short of a specific oblation or offering of the bread and wine to God (such as is found in some other modern Anglican eucharistic liturgies, e.g., The Episcopal Church and Southern Africa). The anamnesis, nonetheless, presents a realist understanding of eucharistic sacrifice by identifying the signs of bread and wine with the celebration of Christ's sacrifice, and the proclamation of Christ's offering on the cross, in resurrection, ascension and coming again, in the context of the Eucharist. The use of the word 'offering' here, in close proximity to the bread and wine, is a clear realist statement not found in earlier prayer books in Australia (e.g., $A n$ Australian Prayer Book ${ }^{37}$ ).

Thanksgiving 2 epiclesis in APBA reads:

Send your Holy Spirit upon us and our celebration that all who eat and drink at this table may be strengthened by Christ's body and blood to serve you in the world. ${ }^{38}$

This gives more specificity about what is the source of strengthening (i.e., Christ's body and blood in the celebration and at the table). It seems, therefore, that in relation to the epiclesis in Thanksgiving 2 of $A P B A$ (1995), there is a more developed realist theology expressed. This, however, does not seem to be the case in relation to the anamnesis in Thanksgiving 2. In an earlier draft form of Thanksgiving 2 the anamnesis reads:

Therefore, living God, as we obey his command, we remember his life of obedience to you, his suffering and death, his resurrection and exaltation, and his promise to be with us for ever. ... We set before you

36. APBA, p. 129.

37. An Australian Prayer Book (AAPB) (Standing Committee of the General Synod of the Church of England in Australia, Sydney: Anglican Information Office Press, 1978).

38. APBA, p. 132. 
these gifts of bread and wine. Accept, we pray, our sacrifice of praise and thanksgiving. ${ }^{39}$

Evan Burge argues that 'the sense of the ancient verbs for "we offer" (Latin offerimus, Greek $\pi \rho \circ \sigma \phi \varepsilon \rho 0 \mu \varepsilon v$ )' may be expressed by 'we draw near to you with this bread and cup' or 'we bring before you this bread and cup' $^{\prime}{ }^{40}$ thereby suggesting that the words 'we set before you these gifts of bread and wine ${ }^{41}$ in the draft form are really an offering or oblation. This argument is strengthened by the next line, which suggests that the request for God to accept the sacrifice of praise and thanksgiving refers back to the 'setting before' God of the bread and wine. This draft statement of oblation is clearly more realist than any expression found in $A P B A$, and therefore, perhaps, unacceptable to certain interests within the Anglican Church of Australia since it was significantly modified in the final form of Thanksgiving 2 in $A P B A$ to become less realist and say:

Therefore, living God, as we obey his command, we remember his life of obedience to you, his suffering and death, his resurrection and exaltation, and his promise to be with us for ever. With this bread and this cup we celebrate his saving death until he comes. Accept we pray our sacrifice of praise and thanksgiving. ${ }^{42}$

The words of oblation ('offer' or 'set before' in the earlier draft) are not used, although the link between the mighty acts of Christ and the elements in the final version of Thanksgiving 2 is made by reference to their celebration with the bread and cup.

One of the more ardent exponents of the fuller catholic (and realist) theology of the Eucharist at the time of General Synod debate on APBA in 1995 was Bishop David Silk, the Bishop of the AngloCatholic Diocese of Ballarat. At the General Synod of 1995, he put forward from the floor of Synod, a new and alternative form of the Thanksgiving not printed in the draft book and not receiving any trial use. Silk describes this prayer as 'an explicitly Catholic text'. ${ }^{43}$

39. The Holy Communion also called the Eucharist and the Lord's Supper (Prepared by the Liturgical Commission of the Anglican Church of Australia for use under section 4 of the Constitution, Sydney: Broughton Books, 1993), p. 37.

40. Evan Burge, 'A Prayer Book for Australia' - A Watershed for Australian Anglicans, (The 1995 Austen Lecture, delivered at St Mary's College, the University of Melbourne, 21 September, 1995), p. 6, Note 58.

41. The Holy Communion, p. 37.

42. APBA, p. 131-132.

43. David Silk, The Holy Eucharist: Alternative and Additional Texts for Use with the Orders of the Eucharist in AAPB and APBA (Authorized and commended by the 
One commentator argued, that in proposing such an addition to the draft material, 'Catholic Anglicans sought a stronger statement of eucharistic offering and epiclesis'. ${ }^{44}$ This prayer was debated at some length, both on the floor of Synod and behind the scenes (see Richardson ${ }^{45}$ and Silk ${ }^{46}$ ), and became in a modified form, Thanksgiving 3 of $A P B A .^{47}$ The epiclesis in Thanksgiving 3 of APBA prays:

Hear us, merciful Lord; through Christ accept our sacrifice of praise; and, by the power of your Word and Holy Spirit, sanctify this bread and wine, that we who share in this holy sacrament may be partakers of Christ's body and blood. ${ }^{48}$

Whereas the other thanksgiving prayers in APBA (1995) refer to the Holy Spirit in relation to the partaking of Christ's body and blood (Thanksgiving 1) or to the Holy Spirit being sent upon the people and the celebration (Thanksgiving 2) or to the power of the Holy Spirit in an unspecified manner (Thanksgiving 4), Thanksgiving 3 specifically prays for a sanctifying of the bread and wine in a distinctly realist manner, suggesting a change in the state of holiness of the bread and wine, so that those who partake of them, partake of Christ's body and blood.

In relation to the anamnesis, Thanksgiving 3 connects the mighty acts of Christ with an offering of a spiritual sacrifice, saying:

Therefore, in obedience to his command, we commemorate and celebrate his saving passion and death, his mighty resurrection and ascension into heaven and we eagerly await his coming again in glory.

We thank you that by your grace alone you have accepted us in Christ; and here we offer you a spiritual sacrifice, holy and acceptable in

(F'note continued)

Bishop of Ballarat under Article 4 of the Constitution of the Anglican Church of Australia, Ballarat: Anglican Diocese of Ballarat, 2nd edn, 2002), p. 8.

44. Gillian Varcoe, 'Implication across the Communion - The Anglican Church in Australia', in David Holeton (ed.), Our Thanks and Praise. The Eucharist in Anglicanism Today. Papers from the Fifth International Anglican Liturgical Consultation (Toronto, Ontario: Anglican Book Centre, 1998), p. 189.

45. David Richardson, 'A Prayer Book for Australia: Historical Background', in Gillian Varcoe (ed.), A Prayer Book for Australia. A Practical Commentary (Sydney: Dwyer, 1997), p. 75.

46. David Silk, Personal telephone conversation and email correspondence with Brian Douglas, regarding the introduction of a new and alternative Thanksgiving Prayer at General Synod, 1995, and the subsequent debate on, voting on and negotiation concerning the prayer, 28 May, 2003 and 24 July, 2003.

47. APBA, pp. 133-135.

48. $A P B A$, p. 134. 
your sight. Through Christ, receive this our duty and service, and grant that we who eat and drink these holy gifts may, by your Spirit, be one body in Christ, and serve you in unity and peace. ${ }^{49}$

There is reference here to a commemoration and celebration of the mighty acts of Christ (paragraph 1), but the connection to this celebration and proclamation is placed at a greater distance from any reference to the bread and wine than is the case in the other thanksgiving prayers (e.g., see Thanksgiving 1, where the words 'we celebrate, with this bread and cup, his one perfect and sufficient sacrifice ${ }^{\prime 50}$ place the celebration of the sacrifice in very close proximity to the bread and wine, such that the celebration is done with the bread and wine). Thanksgiving 3 seems to be a little more reticent about making this realist connection and instead speaks of the commemoration and celebration of Christ's acts with any reference to the bread and wine being several lines later in the word 'gifts'. This is surprising considering the catholic origins of this prayer and its proposer, but may well reflect changes as part of negotiation with other Anglican interests. Despite this, the anamnesis in Thanksgiving 3 uses the words: 'here we offer you a spiritual sacrifice, holy and acceptable in your sight' ${ }^{51}$ To what does the word 'offer' refer? A clue must surely be in the word 'here', suggesting that the offering of a spiritual sacrifice is 'here' in the Eucharist and that this offering is acceptable and holy. 'Here' could refer to the bread and wine, since they are 'here' in the Eucharist, but it could also refer to the offering of a spiritual sacrifice of praise and thanksgiving in the context of 'here' in the Eucharist as an act of praise and thanksgiving. This ambiguity may well be deliberate.

The amendments brought into this prayer, presumably to satisfy Evangelical objections to any concept of oblation in the Eucharist by means of the bread and wine, seem to have cast the theological position and the realist understanding of this Third Thanksgiving Prayer into some doubt. Gillian Varcoe argues that 'evangelicals were intent on protecting the unique atoning work of Christ' and so 'the prayer does not reflect consensus, but is burdened with party code words ${ }^{52}$ and significant repetitiveness. The reference to 'your grace alone' suggests an attempt to make the point that acceptance in Christ is dependent on Christ's grace alone, suggesting a nominalist philosophical assumption

49. $A P B A$, p. 135.

50. $A P B A$, p. 129.

51. APBA, p. 135.

52. Varcoe, 'Implications across the Communion', p. 189. 
aimed at rejecting the realist idea that the eucharistic elements could be vehicles of grace. It seems possible to conclude that attempts to 'insulate' this particular thanksgiving from possible realist understandings, or to any reference to an oblation with the elements, on the basis of party interest, have at the same time limited or lessened any realist understanding of Christ's presence and sacrifice in the Eucharist, which this Thanksgiving prayer may present. It is difficult, therefore, to understand why Thanksgiving 3 was so heavily criticized in the Evangelical Diocese of Sydney by several Evangelical writers (e.g., Woodhouse ${ }^{53}$ and Doyle ${ }^{54}$ ) and by a report of the Doctrine Commission of the Diocese of Sydney ${ }^{55}$ when the other thanksgiving prayers present a more openly realist understanding of both Christ's presence and sacrifice in the Eucharist. Perhaps the strength of the reaction is related to the use of the word 'offer ${ }^{56}$ in Thanksgiving 3, suggesting eucharistic oblation in the Thanksgiving. This conclusion is supported by evidence in the Sydney Doctrine Commission Report on $A P B A$, which says that: 'In Thanksgiving 3 the movement towards a notion of eucharistic sacrifice is most definite of all forms of the prayer of consecration in $\mathrm{APBA}^{\text {' }}$ and as such for these writers represents 'a return to the idea of pre-Reformation liturgies in which the Eucharist ("Thanksgiving") was believed to be itself saving'. ${ }^{57}$ Any suggestion that 'our' sacrifice is part of the Prayer of Consecration is, in the view of the writers of the Sydney Doctrine Commission Report on APBA (1995), 'contrary to the practice of $\mathrm{BCP}^{\prime 58}$ since the $1662 \mathrm{BCP}$ is said to place any reference to a sacrifice of praise and thanksgiving after communion and not in the Prayer of Consecration. These criticisms seem to be firmly based on nominalist philosophical assumptions and on Evangelical theological interests.

One of the consequences of the insertion of Thanksgiving 3 into APBA (1995) was that a form of prayer was adopted that had never

53. John Woodhouse, A Prayer Book for Australia and Reformed, Biblical Christianity. An Evangelical Response to A Prayer Book for Australia (Sydney: Anglican Church League, 1995), online at http:/ / www.acl.asn.au. Accessed 6 January, 2008.

54. Robert Doyle, Expressing the Heart of the Gospel: A Review of the Three Orders of Holy Communion in A Prayer Book for Australia (Sydney: Anglican Church League, 1997), online at http://www.acl.asn.au. Accessed 6 January, 2008.

55. Sydney Doctrine Commission Report 45/95 A Prayer Book for Australia (Sydney: Diocese of Sydney Yearbook, 1997), pp. 450-473.

56. APBA, p. 135.

57. Sydney Doctrine Commission Report, p. 465.

58. Sydney Doctrine Commission Report, p. 467. 
been used in any church (Richardson ${ }^{59}$ and $\operatorname{Varcoe}^{60}$ ). This meant that 'parts of it are awkwardly expressed and difficult to say', but more importantly, Thanksgiving 3, 'represents a departure from the usual Anglican practice of writing liturgy that represent a consensus of the Church as a whole which neither suppresses nor exaggerates particular doctrines. It is not difficult to find within it "code" words representing the doctrinal positions of different factions within the Church'. ${ }^{61}$ Although Richardson does not refer to realism and nominalism, it seems that affirming or denying any linking of the sign and the signified is, in part, the basis of the differences in doctrine negotiated and debated both at the General Synod and behind the scenes. Another consequence of the insertion of Silk's Thanksgiving 3 is that the draft Thanksgiving 3 was completely rejected by the General Synod. Private conversation with Bill Lawton ${ }^{62}$ (a member of the Liturgical Commission which presented the draft APBA [1995] to the General Synod) has revealed that the draft Thanksgiving 3 was written by Evan Burge (at that time also a member of the Liturgical Commission), based on a new translation by Burge of the Apostolic Tradition of Hippolytus, an ancient liturgical text that has significantly influenced liturgical development in the twentieth-century in a number of traditions (e.g., Roman Catholic, Anglican and Uniting) and which as an ancient model presents a realist eucharistic theology. Burge himself observes that draft Thanksgiving 3 'went out in favour of the new Thanksgiving [Silk's] ${ }^{63}$ but reserves further comment, whereas David Richardson (another member of the Liturgical Commission) is less reserved, commenting that: 'It is also a misfortune in practice that the shortest (and most ancient) thanksgiving in the draft book, that based on Hippolytus, was replaced by the longest' ${ }^{64}$ Richardson's distaste for this replacement is hardly concealed and suggests that compromising eucharistic theology, in order to safeguard party positions, is not the best way to proceed in the development of eucharistic liturgies. Gillian Varcoe supports this conclusion and commenting on the party focus, so obvious in the debate at the

59. Richardson, 'A Prayer Book for Australia: Historical Background', p. 75.

60. Varcoe, 'Implications across the Communion', p. 189.

61. Richardson, 'A Prayer Book for Australia: Historical Background', p. 75.

62. Bill Lawton, Personal telephone conversation with Brian Douglas regarding General Synod, 1995 and the production of and debate over A Prayer Book for Australia, 27 and 29 May, 2003.

63. Burge, 'A Prayer Book for Australia' - A Watershed for Australian Anglicans, p. 6.

64. Richardson, 'A Prayer Book for Australia: Historical Background', p. 75. 
General Synod, says that 'mistrust skews communication and results too readily in poor liturgy'. ${ }^{65}$ All this suggests that genuine dialogue (subject-subject) was sacrificed in an attempt to prosecute the theology of party interest (subject-object).

Thanksgiving 5 of the Second Order of the Eucharist in $A P B A^{66}$ is a short thanksgiving in responsive form. The eucharistic theology of Thanksgiving 5 contains the following realist expression: 'And now we thank you for these gifts of bread and wine; may we who receive them, as Jesus said, share his body and his blood'. ${ }^{67}$

There is a clear realist link between the bread and wine, the receiving of them and the sharing of Christ's body and blood. Realist linking is also expressed in the words following the institution narrative, which say: 'You have gathered us together to feed on Christ and to remember all he has done for us'. ${ }^{6}$

Here, the mighty works of Christ are expressed in a generalized way ('all he has done for us') and this is linked in a realist way with the gathering together in the Eucharist and with the feeding on Christ.

The Third Order of APBA (1995)

The Third Order of the Eucharist in $A P B A^{69}$ reflects modern liturgical shape, but does not express such explicit realist theology of the Eucharist as is found in the Second Order. While some Evangelicals see the Third Order as having 'simple theological clarity' ${ }^{70}$ and the possessing of 'several indicators of substitutionary atonement' as commendable and therefore 'very welcome', ${ }^{71}$ others viewed the Third Order from a catholic and realist perspective as lacking 'adequate reference to the sacramental bread and cup as a divinely appointed sacramental means of feeding on Christ' ${ }^{72}$ Some, such as Bishop Silk in the Anglo-Catholic Diocese of Ballarat, went as far as saying that the Third Order is 'not recommended ${ }^{73}$ and expressive of

65. Varcoe, 'Implications across the Communion', p. 189.

66. АPBA, pp. 139-140.

67. $A P B A$, p. 140.

68. $А P B A$, p. 140.

69. АРBA, pp. $167-180$.

70. Sydney Doctrine Commission Report, p. 469.

71. Doyle, Expressing the Heart of the Gospel, p. 25-26.

72. Burge, 'A Prayer Book for Australia - A Watershed for Australian Anglicans', p. 3, Note 47.

73. David Silk, The Holy Eucharist: Alternative and Additional Texts for Use with the Orders of the Eucharist in $A A P B$ and $A P B A$ (Authorized and commended by the 
'the Protestant doctrine of the $1552 \mathrm{BCP}^{\prime} .{ }^{74}$ This suggests that while some (Burge ${ }^{75}$ and Silk $^{76}$ ) see the application of a realist sacramental principle in the Eucharist as appropriate according to their particular Catholic view of eucharistic theology, others ${ }^{77}$ do not and prefer a eucharistic theology based on the philosophical assumptions of nominalism. ${ }^{78}$ Whatever the intent of the writers of the Third Order Eucharist of $A P B A$, it seems to present a eucharistic liturgy which expresses a specifically less realist theology of the Eucharist than the Second Order of APBA (1995).

The Third Order Eucharist contains no epiclesis or oblation, although there is some realist linking of the signs of bread and wine with the mighty acts of Christ in the following anamnesis:

And now, gracious God, we thank you for these gifts of bread and wine, and pray that we who receive them, in the fellowship of the Holy Spirit, according to our Saviour's word, in remembrance of his suffering and death, may share his body and blood. ${ }^{79}$

The linking here seems to be between the bread and the wine, the receiving of them, the sharing of Christ's body and blood and the remembering of Christ's suffering and death. This suggests a receptionist ${ }^{80}$ emphasis here, such as is found in the $1552 \mathrm{BCP}$, with any realist linking of the signs of bread and wine with the signified body and blood of Christ, limited to the action of receiving. Burge argues that the Liturgical Commission included the Third Order 'for its simplicity and doctrinal congruity with the $B C P$, but not to gratify one party'. ${ }^{81}$ Despite Burge's assertion, it seems that the Third Order is more acceptable to Evangelical interests precisely because it gratifies nominalist assumptions of eucharistic theology, in much the same

(F'note continued)

Bishop of Ballarat under Article 4 of the Constitution of the Anglican Church of Australia, Ballarat: Anglican Diocese of Ballarat, 1st edn, 1995), p. 201.

74. Silk, The Holy Eucharist, 2nd edn, 2002, p. 7.

75. Burge, 'A Prayer Book for Australia' - A Watershed for Australian Anglicans.

76. Silk, The Holy Eucharist, 1st and 2nd edn.

77. Sydney Doctrine Commission Report and Doyle, Heart of the Gospel

78. Even if these philosophical assumptions are not implicitly stated.

79. $А P B A$, p. 176.

80. Receptionism holds that while the bread and wine continue to exist unchanged after consecration, the faithful communicant receives together with them the Body and Blood of Christ.

81. Burge, 'A Prayer Book for Australia' - A Watershed for Australian Anglicans, p. 3, Note 47 . 
way the Second Order is more acceptable to Catholics because it gratifies realist assumptions of eucharistic theology. In the same way, the Third Order is unacceptable to some Catholics ${ }^{82}$ because it does not present a sufficiently catholic and realist analysis of what happens in the Eucharist, just as the Second Order is unacceptable to some Evangelicals ${ }^{83}$ because it presents a eucharistic theology which is too realist.

\section{Liturgical Responses to APBA 1995}

Two significant liturgical responses have occurred since the publication of A Prayer Book for Australia (1995) - one in the Anglo-Catholic Diocese of Ballarat and another in the Evangelical Diocese of Sydney. Each will now be considered in terms of the philosophical assumptions underlying the eucharistic theology of these liturgies.

\section{'The Holy Eucharist' of the Diocese of Ballarat}

In the Anglo-Catholic Diocese of Ballarat, a manual entitled The Holy Eucharist ${ }^{84}$ attempts to correct what are seen as deficiencies in APBA (1995) and present alternative forms of the Thanksgiving (as well as material not included in APBA), so as to provide liturgies 'capable of Catholic interpretation' ${ }^{85}$ or 'patient of a Catholic interpretation'. ${ }^{86}$

In amending Thanksgiving 1 of APBA (1995), Silk makes the following additions (in italics):

Merciful God, we thank you for these gifts of your creation, this bread and this wine, and we pray that by your Word and Holy Spirit, we who eat and drink them may by them be partakers of Christ's body and blood. ${ }^{87}$

The intention here seems to be to identify the signs of bread and wine more closely with the signified body and blood of Christ. By adding the words 'by them' an emphasis of a realist theology of Christ's eucharistic presence is made, whereby the communicant is made a partaker of Christ's body and blood by the elements ('them').

In amending Thanksgiving 2 of APBA (1995), Silk makes the following additions (in italics) to the anamnesis: 'With this bread and this cup we celebrate his saving death and sacrifice until he comes'. ${ }^{88}$

82. Silk, The Holy Eucharist, 1st and 2nd edn.

83. Doyle, The Heart of the Gospel.

84. Silk, The Holy Eucharist, 1st edn (1995) and 2nd edn (2002).

85. Silk, The Holy Eucharist, 1st edn, p. 198.

86. Silk, The Holy Eucharist, 2nd edn, p. 8.

87. Silk, The Holy Eucharist, 2nd edn, p. 138.

88. Silk, The Holy Eucharist, 1st edn, p. 111. 
The sense here seems to be that in the Eucharist there is a celebration, not only of Christ's death but also his sacrifice and that this celebration of sacrifice continues until Christ returns. Here then is a realist linking of the Christ's death and sacrifice linked with the celebration of the Eucharist and, specifically, with the bread and cup.

In relation to the amendments put forward for Thanksgiving 5 of APBA (1995) Bishop Silk argues that Thanksgiving 5, 'lacks memorial (anamnesis) and an invocation (epiclesis) related to the eucharistic action'. ${ }^{89}$ Accordingly, to rectify this situation, Silk amends (in italics) Thanksgiving 5 in the following way:

Loving Father, you have gathered us together to remember all that Jesus did to save us. In this holy sacrifice which he gave as a gift to his Church we remember his dying and his rising. Fill us with the joy of the Holy Spirit as in this holy meal we receive the body and blood of your Son. ${ }^{90}$

Silk intends that the Eucharist is a sacrifice, coming to the Church from Christ himself, and that it is by this sacrifice in the Eucharist that Christ's dying and rising is remembered and Christ's body and blood is received. These amendments are realist - identifying the signs of bread and wine with the body and blood of Christ, and the sacrifice of Christ's death with the sacrifice of the Eucharist.

In relation to the epiclesis, Silk makes the following amendments (in italics): 'And now we thank you for these gifts of bread and wine; bless them and make them holy, that we who receive them, as Jesus said, may share his body and blood'. ${ }^{91}$

The intention of blessing the bread and wine is to make them holy, so that those who receive them may share Christ's body and blood. This is a more realist interpretation than Thanksgiving 5 of APBA (1995) intended. Silk later ${ }^{92}$ rejects the theology and use of Thanksgiving 5 and no longer recommends the use of Thanksgiving 5 , arguing that Thanksgiving 5 'is drafted in such a way as to exclude the catholic understanding of the Eucharist and to reflect the doctrinal position of 1552 - the real presence is in the heart of the believer, and the memorial is in the reception rather than the offering, ${ }^{93}$

89. Silk, The Holy Eucharist, 1st edn, p. 198.

90. Silk, The Holy Eucharist, 1st edn, p. 120.

91. Silk, The Holy Eucharist, 1st edn, p. 119.

92. In the 2nd edn of The Holy Eucharist, published in 2002.

93. Silk, The Holy Eucharist, 2nd edn, p. 8. 


\section{'Sunday Services' of the Diocese of Sydney}

In the Evangelical Diocese of Sydney, a set of liturgical resources, entitled Sunday Services. A Contemporary Liturgical Resource was published in 2001 by the Archbishop of Sydney's Liturgical Panel. The publication was authorized by Archbishop Peter Jensen, following on from work actually begun by his predecessor, Archbishop Harry Goodhew, in an attempt to provide liturgical resources that are 'biblical in content, intelligible in language and appropriate to our time and culture'. ${ }^{94}$ Sunday Services also claims to stand firmly within the Reformation tradition of Archbishop Cranmer ${ }^{95}$ and to present several eucharistic liturgies, or Services of the Lord's Supper or Holy Communion, which reflect this tradition. ${ }^{96}$

Form 1 of Sunday Services (style of $1662 B C P$ ) focuses on the death of Jesus Christ and gives emphasis to the theological concepts of atonement and justification by faith. These themes are most apparent in the Prayer of Consecration where the following is found:

We thank you our heavenly Father that in your love and mercy you gave your only Son Jesus Christ to die on the cross to save us. By this offering of himself once and for all time, Jesus made the perfect, complete sacrifice for the sins of the whole world, satisfying your just demands in full. ${ }^{97}$

The work of the cross is emphasized and the other mighty acts of Christ (resurrection and ascension) are not mentioned. There is a nominalist separation in these liturgies between the work of Christ on the cross or remembering his death until his coming again and the Eucharist. In the next paragraph however, are found these words: 'Hear us, merciful Father, and grant that we, who eat and drink this bread and wine, may remember his death, and share in his body and blood'. ${ }^{98}$

There is no clear realist link between the signs of bread and wine and the body and blood of Christ or the remembering of Christ's death. The act of eating and drinking the bread and wine does not

94. Sunday Services. A Liturgical Resource prepared by the Archbishop of Sydney's Liturgical Panel (Sydney: Anglican Press Australia, 2001), p. 2, online at http:// sundayservices.net. Accessed 6 January, 2008.

95. Douglas, Anglican Eucharistic Theology, case study 1.1 analyses Cranmer's eucharistic theology and concludes that it is based on nominalist philosophical assumptions. Online at http://web.mac.com/brian.douglas. Accessed 6 January, 2008.

96. Sunday Services, p. 3.

97. Sunday Services, p. 55.

98. Sunday Services, p. 55. 
necessarily have any link with the remembering and the sharing, apart from the fact that the act of eating and drinking are seen to be occurring at the same time as the sharing in Christ's body and blood, and at the time that the communicant is bringing to mind the death of Christ.

The institution narrative follows with no epiclesis or anamnesis and reception of communion follows immediately after the 'Amen' with no anthems or acclamations - all this being in the pattern of the 1662 $B C P$ service of Holy Communion.

Form 2A of Sunday Services (modern liturgical shape) however, refers to the mighty acts of Christ other than his death (resurrection and coming again) and to Christ's sacrifice as once offered, a true sacrifice for sin, a reconciliation and satisfaction of God's just demands and as the means of securing eternal deliverance. ${ }^{99}$ The institution narrative follows and then the people join the minister in saying: 'Therefore Father, we thank you for these gifts of bread and wine, and pray that we who eat and drink them, believing our Saviour's word, may share his body and blood'. ${ }^{100}$

It is the eating and the drinking that is linked to the sharing of the body and blood and not the signs of bread and wine. This seems to be expressing a receptionist doctrine and not a realist identification of the sign with the signified. This is emphasized by the exchange between ministers and people which follows where the following words are used:

We eat the bread and drink the cup of the Lord

to proclaim our fellowship in his death.

We do this until he returns

Come Lord Jesus, come! $!^{101}$

Once again, it is the eating and drinking (receptionism) that is linked with the proclamation, not the signs of bread and wine, thereby lessening any idea of realism. The signs of bread and wine and the signified body and blood of Christ are separated entities, and the eucharistic theology of this service and that following (Sunday Services 2B) depend on nominalist philosophical assumptions rather than realism.

\section{Conclusion}

The case study of APBA (1995) of the Anglican Church of Australia and two of the liturgical alternatives in use in that church, suggest that hermeneutic idealism is alive and well in the Anglican Church of

99. Sunday Services, pp. 66-67.

100. Sunday Services, p. 67.

101. Sunday Services, p. 67. 
Australia at both a national and diocesan level. APBA (1995) seeks to accommodate the different eucharistic theologies of the parties and interests in the Anglican Church of Australia by providing a variety of eucharistic liturgies. The liturgies rest on different philosophical assumptions with The Second Order expressing a eucharistic theology based more on realist philosophical assumptions, and The Third Order on philosophical assumptions that are somewhat less realist. Despite this, there are some who see the need to produce and use a liturgical alternative to satisfy their particular interests (e.g., the Diocese of Sydney and the Diocese of Ballarat). Others, such as Varcoe, ${ }^{102}$ argue that many Anglican Catholics, although prepared to use the Second Order of APBA (1995), would have preferred a stronger statement of eucharistic offering and epiclesis.

The application of a Habermasian model of dialogue and communicative action to the production of eucharistic liturgies would involve a very different process from that which presently exists in the Anglican Church of Australia and which has produced APBA (1995). The current approach to the development of eucharistic liturgies features negotiation and argumentation between church parties and interest concerning liturgical product - a subject-object process where subjects (supporters of party interests) debate an object (eucharistic theology and party interest) in order to produce a eucharistic text acceptable to all. This occurs before, after and during the General Synod process. Although this has at times resulted in mutually agreed positions, it has also produced acrimony and the infusion of party spirit into the debate where battles between parties are hard fought and particular positions are asserted with considerable vigour and antagonism. The liturgical reaction of the Bishop of the Diocese of Ballarat ${ }^{103}$ towards The Third Order of the Eucharist in APBA (1995) reflects Anglican Catholic interest in dismissing this order, while the liturgical reaction of the Diocese of Sydney ${ }^{104}$ to APBA reflects a distinctly Anglican Evangelical interest. With both of these dioceses pursuing their own way, the chances for dialogue are lessened even more and the process of subject-object takes precedence in the debate. At less strident levels, the fact that the form of Thanksgiving proposed by Evan Burge at the 1995 General Synod of the Anglican Church of Australia was rejected and replaced with a version unsatisfactory to all parties (see the views of Varcoe ${ }^{105}$

102. Varcoe, 'Implications across the Communion', p. 189.

103. Silk, The Holy Eucharist, 1st and 2nd edn.

104. Sunday Services.

105. Varcoe, 'Implications across the Communion'. 
and Lawton $\left.{ }^{106}\right)$, suggests that decisions were made in order to satisfy party interest without real dialogue of the subject-subject type. A better approach to the development of eucharistic liturgies might well have focused on a subject-subject approach, such as Habermas suggests in his theory of communicative action. ${ }^{107}$ Under such a proposal, each party would have made the effort to engage in dialogue with the other party in an attempt to promote the intersubjectivity of communicative action, that is, self-reflection on their own knowledge and interests and on the knowledge and interests of others. Agreement could then be reached, not in terms of a mutually acceptable eucharistic theology (if this is ever possible), but in terms of the acceptance of multiformity of eucharistic theology and the genuine desire to hear what another party is saying. In practice, this may mean that Anglican Catholics would use a eucharistic liturgy which expresses a fuller catholic and realist theology, and Anglican Evangelicals use a eucharistic liturgy with a reformed emphasis on the atonement and underlying nominalist philosophical assumptions. Such a situation recognizes the multiformity of the Anglican eucharistic tradition in terms of theological and philosophical assumptions, does not try to mute the eucharistic theology of any or all interests and provides for a situation of liturgical practice that may well be more acceptable to all parties. The process becomes one of dialogue rather than acrimonious debate and, where the emphasis is on the acceptance of multiformity rather than the prosecution of partisan interest to the exclusion of communicative action. This does not mean that various parties can develop any liturgical product that their disposition favours, but rather that the General Synod in its drafting recognizes the multiformity of philosophical assumptions underlying different eucharistic liturgies and that those of particular parties also recognize that multiformity exists. Such a process limits the prosecution of hermeneutic idealism and recognizes the legitimacy of multiformity.

Anglican eucharistic theology comprises a multiformity of eucharistic theology based on different eucharistic theologies, expressed both in systematic theological ways and in eucharistic liturgies. This article has argued that one way these differences can be explored and better understood is by using the philosophical assumptions of realism and nominalism that underlie these different theologies and their attached liturgies. In this way, philosophical analysis holds out the potential of

106. Lawton, Telephone conversation.

107. Habermas, Theory, Volume 1 and Theory, Volume 2. 
promoting dialogue and communicative action within the Anglican eucharistic tradition because of its more critical focus. It can do this because this analysis has the potential to distance the discussion from the acrimonious arguments, so often associated with party spirit, and the hermeneutic idealism of these parties. In doing this, it can provide for more productive speaking and listening on the part of all participants in the Anglican tradition. 